\title{
CS-11 Sistema de puntuación HOSPITAL como predictor del reingreso en pacientes con insuficiencia cardiaca
}

\author{
HOSPITAL score as predictor of readmission in patients with heart failure \\ Diego F. Salazar*, Kevin D. Zelada, Edgar L. Choche, Harry F. Soto, Hany M. Soto \\ Facultad de Ciencias Médicas, Universidad de San Carlos de Guatemala, Guatemala
}

*Autor al que se dirige la correspondencia: diegofabiansalazar@gmail.com

\section{Resumen}

$\mathrm{E}$ 1 sistema de puntuación HOSPITAL es una herramienta que determina la probabilidad de reingreso a 30 días

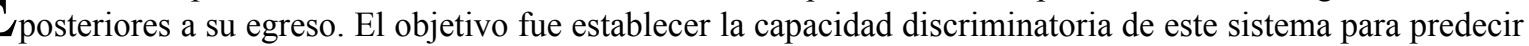
el reingreso de pacientes mayores de 18 años con diagnóstico de insuficiencia cardiaca con fracción de eyección ventricular izquierda menor o igual a $40 \%$ en los 30 días posteriores a su egreso, ingresados de enero a noviembre del 2016 en los hospitales San Juan de Dios y Pedro Bethancourt. Se realizó un estudio de pruebas diagnósticas con 56 expedientes clínicos, elaborando una curva ROC (Receiver Operating Characteristic), donde se estableció el área bajo la curva que calculó la capacidad discriminatoria y mediante el índice de Youden se estableció el punto de corte con mayor sensibilidad y especificidad. Se estimó el valor predictivo positivo, negativo y la razón de verosimilitud positiva y negativa para dicho punto de corte. Se encontró un área bajo la curva de .874 IC 95\% [.784 - .964], con un punto de corte de mayor sensibilidad (92\%) y especificidad (78\%) de 6 puntos. Con valores predictivos negativo y positivos de $97 \%$ y $52 \%$ respectivamente y razón de verosimilitud positiva de 4.18 y negativa de 0.10 . Este sistema posee capacidad discriminatoria para predecir el reingreso de pacientes con insuficiencia cardiaca dentro de los primeros 30 días posteriores a su egreso, clasificando a un paciente con baja probabilidad de reingreso si obtiene un puntaje menor a 6 y como alta probabilidad con un puntaje mayor a seis.

Palabras claves: Curva ROC, sensibilidad, especificidad, valor predictivo, razón de verosimilitud

\section{Abstract}

$\mathrm{T}$ he HOSPITAL score is a tool that determines the probability of readmission 30 days after discharge. The objective was to establish the discriminatory capacity of this score to predict the readmission of patients over 18 years of age with a diagnosis of heart failure with a left ventricular ejection fraction less than or equal to 40\% within 30 days after discharge in the period from January to November 2016 in the hospitals San Juan de Dios and Pedro Bethancourt. A study of diagnostic tests was carried out with 56 clinical records, elaborating a ROC (Receiver Operating Characteristic) curve, where the area under the curve was delimited that calculated the discriminatory capacity, and through the Youden index, the cutting point with greater sensitivity and specificity was created. The positive, negative predictive value and the positive and negative likelihood ratio for the cut-off point were estimate. An area under the curve of $.87495 \%$ CI [.784 - .964] was found, with a cut point of greater sensitivity (92\%) and specificity (78\%) of 6 points. With negative and positive predictive values of $97 \%$ and $52 \%$ respectively and a positive likelihood ratio of 4.18 and negative of 0.10 . This score has discriminatory capacity to predict the readmission of patients with heart failure within the first 30 days after discharge, classifying a patient with a low probability of readmission if he scores below 6 and as high probability with a score higher than six.

Keywords: ROC curve, sensitivity, specificity, predictive value, likelihood ratio 